Michał Niewodowski

(D) https://orcid.org/0000-0003-2537-9566

\title{
Historia agencji prasowych na świecie
}

(6) https://doi.org/10.15633/9788363241131.01

\section{Geneza agencji prasowych}

Na początku było słowo, a później ludzie wynaleźli pismo. Gdy już Gutenberg w Xv wieku opracował prasę drukarską, czytelnictwo stało się powszechne i stworzyło zapotrzebowanie na informacje. Ludzie byli ciekawi tego, co dzieje się na świecie, a żeby zaspokoić tę potrzebę wiedzy, zakładano gazety. Opisuje to medioznawca prof. Zbigniew Bajka: „Rozwój prasy europejskiej w XVII wieku i na początku XX wieku, w tym powstanie wielu dzienników, zarazem bardzo ważne wydarzenia polityczne i militarne na Starym Kontynencie i w Ameryce Północnej, spowodowały rosnące zainteresowanie informacjami zwłaszcza z obcych krajów”'. Wraz z rozwojem cywilizacji odległości między państwami i kontynentami zaczęły się „kurczyć”. Mając większą świadomość świata, ludzie coraz bardziej byli ciekawi, co dzieje się po drugiej stronie globu albo w krajach sąsiednich. Gazety, żeby sprostać oczekiwaniom czytelników, wysyłały swoich korespondentów po całym świecie. Jednak takie ekspedycje nie tylko były kosztowne, ale nie zawsze przynosiły zamierzony efekt. W czasach, gdy

1 Z. Bajka, Historia mediów, Kraków 2008, s. 72. 
nie było internetu i powszechnego dostępu do informacji, korespondent był jedynym „wiarygodnym” źródłem informacji i trzeba było mu uwierzyć na słowo. Tylko najwięksi potentaci prasy mogli sobie pozwolić na utrzymywanie pracowników w innych miastach czy krajach. Małych, lokalnych dzienników nie było stać na korespondentów, a przecież ich czytelnicy też chcieli wiedzieć, co dzieje się na świecie. Zapotrzebowanie na informacje nadal rosło i wtedy pojawił się Charles Havas.

\section{Agencje Havas, Reutera i Wolffa. Narodziny pierwszych wielkich graczy}

Charles-Louis Havas założył pierwszą na świecie agencję prasową w 1835 roku w Paryżu. Początkowo prowadził on biuro tłumaczeń przy ulicy Jeana-Jacques’a Rousseau. Wpadł na pomysł, że może dostarczać ministerstwom i ambasadom ulokowanym w Paryżu, na zasadzie abonamentu, wyciągi z prasy zagranicznej. Taki serwis prasowy zainteresował redakcję dziennika „Le Constitutionnel”" , która stała się pierwszym komercyjnym klientem biura Havas. To zdarzenie było impulsem do przemienienia biura tłumaczeń $\mathrm{w}$ agencję prasową. W ślad za dziennikiem „Le Constitutionnel” podążyły francuska prasa, a także banki, biura maklerskie oraz organizacje gospodarcze. Roman Starzyński zapotrzebowanie na informacje Havasa opisywał tak: „poza kilku większymi dziennikami paryskimi cała prasa francuska, zwłaszcza prowincjonalna, w serwisie Havasa znajduje całokształt materiału informacyjnego o zdarzeniach zagranicznych, politycznych, wewnętrznych”3. Agencja francuska początkowo korzystała z gołębi pocztowych oraz sieci kurierów. W 1848 roku Havas zaczął korzystać z połączeń telegraficznych.

Kolejne europejskie agencje prasowe powstały w Niemczech (1849 rok - agencja Bernharda Wolffa) i w Wielkiej Brytanii (1851 rok - agencja Juliusa Reutera), korzystając z nowego połączenia telegraficznego między Paryżem, Berlinem i Londynem ${ }^{4}$. Warto zauważyć, że to właśnie polep-

2 R. Starzyński, Agencje informacyjne. Dzieje, stan obecny $i$ znaczenie prasowych agencji telegraficznych, Warszawa 1935, s. 7.

3 Tamże, s. 8 .

4 R. Borkowski, Informacyjne agencje prasowe, Kraków 1976, s. 12. 
szenie systemu komunikacji zachęciło Wolffa i Reutera do otwarcia własnych działalności. Od uruchomienia połączenia telegraficznego agencja niemiecka potrzebowała ośmiu tygodni, żeby ruszyć ze swoją służbą prasową. Anglikom zajęło to trzy lata. Co ciekawe, Wolff i Reuter nie byli ludźmi z przypadku. Swoją wiedzę na temat funkcjonowania agencji prasowych zdobyli jako korespondenci agencji Havas. Kradzież know-how nie zepsuła stosunków między agencjami. Cała trójka współpracowała ze sobą, powiększając swoje zasięgi i przy okazji tworząc coraz większą sieć połączeń telegraficznych. Klienci ich serwisów prasowych byli bardzo podobni, choć mówili w innych językach. Ważny dla prestiżu Reutera był dziennik „The Times”, który jako tytuł z tradycjami, początkowo nie chciał korzystać z informacji agencyjnych. W 1858 roku przedrukowano jednak na jego łamach przemówienie Napoleona III, przekazane kablem $\mathrm{z}$ Paryża, prosto do agencji Reutera ${ }^{5}$.

Agencja niemiecka wywodziła się z gazety „Nazionalzeitung”. Jej wydawcą był dr Bernhard Wolff. Pierwszą informacją podaną przez jego biuro telegraficzne było notowanie giełdowe z Londynu ${ }^{6}$. „W 1870 roku trzy współpracujące ze sobą agencje prasowe, Havas, Wolff i Reuters zawarły umowę dotyczącą podziału stref ich wpływów w świecie”7. Havas otrzymał kraje romańskie i Amerykę Południową. Wolffowi w udziale przypadły północna i wschodnia Europa. Reuters zajął się Wielką Brytanią, Holandią oraz wszystkimi nieeuropejskimi częściami świata ${ }^{8}$. Europa Wschodnia okazała się trudnym rynkiem dla Wolffa. Niemcy musieli tutaj konkurować z rosyjską TAss, czyli Telegrafnoje Agenstwo Sowietskogo Sojuza, która od momentu założenia w 1925 roku była uważana za agencję globalną ${ }^{9}$. Wcześniej w jej miejscu działały Petersburska Agencja Telegraficzna oraz Rosta, czyli Rossijsko Telegrafnoje Agenstwo.

Agencje Havas, Reuters i Wolff nie tylko rozwijały sieci telegraficzne i sieci kontaktów. $\mathrm{Z}$ ich inicjatywy powstawały nowe biura prasowe. W 1867 roku Havas założył agencję Fabra w Hiszpanii, a także agencję portugalską. W tym samym roku Wolff powołał agencję szwedzko-norweską.

5 H. Kurta, L. Meissner, Prasa za granica, Warszawa 1972, s. 331.

6 R. Starzyński, Agencje informacyjne, dz. cyt., s. 29.

7 L. Słupek, agencja prasowa w: Stownikterminologii medialnej, pod red. W. Pisarka, Kraków 2006, s. 4 .

8 R. Starzyński, Agencje informacyjne, dz. cyt., s. 27.

9 H. Kurta, L. Meissner, Prasa za granica, dz. cyt., s. 184. 
W tej formie nie utrzymała się jednak długo. Zaledwie rok od powołania w 1868 podzieliła się na: Tidningarnas Telegrambyra Aktiebolag w Sztokholmie i Norsk Telegrambyrå w Oslo. Reuter działał w Holandii, zakładając Nederlandsch Telegraaf Agentschap. Pod koniec xıx wieku Havas zainteresował się Bałkanami. Z jego inicjatywy powstały tam Serbska Agencja Telegraficzna oraz w 1906 roku Agencja Ateńska ${ }^{10}$.

Z wielkiej „trójcy” agencji prasowych jako jedyny przetrwał Reuters. Havas i Wolff nie przetrwały II wojny światowej. Reuters radzi sobie znakomicie. Dziś, tak jak prawie dwieście lat temu, jest to jedna z największych agencji informacyjnych na świecie. Dzięki swojej platformie Reuters Connect dostarcza depesze, nagrania dźwiękowe, wideo oraz zdjęcia do prawie wszystkich największych redakcji newsowych. Każdy może skorzystać z ich bogatego archiwum, sięgającego samych początków pracy $\mathrm{z}$ aparatem i kamerą. Do dziś serwis Reutersa jest synonimem rzetelnej i dobrze zredagowanej informacji.

\section{Agencje w amerykańskim stylu}

Kiedy w Europie dominował Havas, a Reuter i Wolff jeszcze byli jego korespondentami, za oceanem trwała wojna między Stanami Zjednoczonymi oraz Meksykiem, zwana wojną meksykańską. Był rok 1846, czyli sam początek konfliktu. Zapotrzebowanie na wiadomości z frontu było już tak duże, że narastały złość i frustracja spowodowane opieszałością amerykańskiej poczty. Obywatele Stanów byli żądni wiadomości, ale z frontu nic nie napływało. Wtedy pięć nowojorskich gazet wpadło na pomysł założenia Associated Press i powołania do życia Pony Express, czyli pierwszego prywatnego szlaku informacyjnego wiodącego przez Alabamę w kierunku północnym. Cel był jeden - wyprzedzić Urząd Pocztowy us, a tym samym zadowolić czytelników ${ }^{11}$. Do Associated Press przylgnęła chlubna łatka „Marine Corps dziennikarstwa” - zawsze pierwsi i do samego końca w miejscu, gdzie coś się dzieje. W całej historii agencji ponad trzydziestu dziennikarzy AP oddało swoje życie w tej pogoni za informacją.

10 R. Starzyński, Agencje informacyjne, dz. cyt., s. 14.

11 http://www.ap.org/company/history/ap-history, 22.05.2021. 
W 1907 roku na rynku amerykańskim, a później globalnym, powstało United Press International. Twórcą tej nowojorskiej agencji był E. W. Scripps, który połączył ze sobą trzy małe syndykaty prasowe. Agencje amerykańskie od samego początku stawiały na kompleksowość obsługi mediów. UPI produkowało serwis prasowy, fotograficzny, radiowy i filmowy ${ }^{12}$. Kompleksowość usług medialnych jest domeną współczesnych agencji informacyjnych. Dziś taki kontent dostarczają Reuters Connect, ENEX czy AFP. Również Associated Press dysponuje szeroko rozwiniętym kanałem dystrybucji treści dla wszelkiego rodzaju mediów.

O sile AP i UPI może świadczyć ich konfrontacja z Reutersem. Londyńska agencja przez długi czas toczyła zaciekły bój o rynki informacyjne na świecie. Na podstawie porozumienia Havas-Reuters-Wolff jasno określono strefy wpływów. Brytyjczykom przypadały udziały w dawnych koloniach, w tym w Stanach Zjednoczonych. Reuters oficjalnie odpowiadał za wymianę informacji między usa a Starym Kontynentem, co przeszkadzało w interesach AP i UPI. Wszystko zaogniło się po I wojnie światowej. Początek xx wieku nie był łaskawy dla Europy, co skrupulatnie wykorzystali Amerykanie. Zaledwie szesnaście lat zajęło agencjom zza oceanu rozmontowanie starego układu sił w Europie i na świecie. W 1934 roku AP i UPI doprowadziły do anulowania wszystkich poprzednich porozumień o podziale stref wpływów. Otworzyło im to możliwość nieograniczonego działania. Drugim ważnym momentem był okres po II wojnie światowej. Agencje amerykańskie rozbudowały sieć swoich korespondentów i placówek w Europie, a także zaczęły wypierać Reutersa z krajów Ameryki Łacińskiej ${ }^{13}$. Dobra passa Amerykanów trwa nadal. upI działa do dziś na rynku prasowym. AP przetrwała w niezmienionym kształcie. Zmieniły się tylko sposoby i format dystrybuowanych informacji. Associated Press jako światowa agencja dostarcza: depesze, zdjęcia, nagrania audio oraz wideo. Jedną z przyczyn długowieczności AP jest jej umiejętność wdrażania nowych technologii komunikacyjnych. Agencja przeszła drogę z dostarczania wiadomości przez gołębia, Pony Express, kolej, parowiec, telegraf i dalekopis we wczesnych latach. Po drodze w 1935 roku zaczęto przesyłać treści za pomocą połączenia kablowego, a w 1973 roku dystrybuowano je za pomocą radia. Od 2005 roku AP dysponuje cyfrową platformą, która

12 H. Kurta, L. Meissner, Prasa za granica, dz. cyt., s. 280.

13 Tamże, s. 332. 
gromadzi i daje dostęp do wszystkich treści agencyjnych. Pozwala to agencji dostarczyć informacje w błyskawicznym tempie.

Pracownicy AP mają 280 biur w ponad 100 krajach. Agencja pozostaje not for profit, jest spółdzielnią należącą do 1500 amerykańskich gazet, które są zarówno jej klientami, jak i jej członkami ${ }^{14}$. „W swojej historii Associated Press zdołała pierwsza powiedzieć światu o wielu najważniejszych momentach w historii, od zabójstwa Abrahama Lincolna i zbombardowania Pearl Harbor po upadek szacha Iranu i śmierć papieża Jana Pawła II"15.

\section{Nie każdy może być agencją, czyli czym był Międzynarodowy Związek Agencji Informacyjnych}

Havas, Reuters oraz Wolff to święta trójca dziennikarstwa agencyjnego. Ich właściciele się znali, lubili i robili wspólne interesy. Jak wspominano wcześniej, ich umowa o współpracy dzieliła na trzy strefy wpływów ówczesny świat. Rynek agencji prasowych zaczynał się jednak powoli zapełniać. Nie bez znaczenia w tym procesie była I wojna światowa. W krajach, które dopiero odzyskały wolność, zaczęły pojawiać się nowe, krajowe agencje prasowe. Działo się to na fali entuzjazmu po odzyskaniu suwerenności i prawdopodobnie miała być to próba pokazania niezależności także w tej dziedzinie ${ }^{16}$.

Właśnie dlatego 12 grudnia 1923 roku Havas i Reuters przyjęły zaproszenie Szwajcarskiej Agencji Telegraficznej (ATS), by usiąść do stołu i porozmawiać z przedstawicielami 22 krajowych agencji informacyjnych. Większość uczestników tej konferencji już wcześniej współpracowała z Havasem i Reutersem. Niezwykłe w tym spotkaniu było jednak to, że po raz pierwszy w historii przedstawiciele agencji krajowych rozmawiali ze swoimi znacznie większymi kolegami jak równy z równym. Nieprzypadkowo na miejsce spotkania wybrano Berno. Neutralna Szwajcaria była pośrednikiem i łącznikiem pomiędzy rozdzielonymi przez wojnę częściami Europy. Co jednak najważniejsze, efektem konferencji berneńskiej

\footnotetext{
14 Media: leksykon PWN, red. Edyta Banaszkiewicz-Zygmunt, Wydawnictwo Naukowe Pw , Warszawa 2000, s. 109.

16 R. Starzyński, Agencje informacyjne, dz. cyt., s. 15.
} 
było powołanie Ligi Agencji, czyli Międzynarodowego Związku Agencji Informacyjnych (MZAI). W jego skład weszły: Amtliche Nachrichtenstelle (ANA) z Austrii, Agence d’Athenes z Grecji, której założycielem był Havas, Belgijska Agencja Telegraficzna (Belga), Bułgarska Agencja Telegraficzna (BTA), Československá tisková kancelář (ČTK), Litewska Agencja Telegraficzna (Elta), Estońska Agencja Telegraficzna (ETA), agencja hiszpańska Fabra, Havas, Łotewska Agencja Telegraficzna Leta, Węgierska Agencja Telegraficzna (мті), holenderska Nederlandsch Telegraaf Agentschap (Nederlandsch), Polska Agencja Telegraficzna, Orient Radio (Rador), duńska Ritzaus Bureau, Reuters, włoska Agenzia Stefani, Szwajcarska Agencja Telegraficzna, szwedzka Tidningarnas Telegrambyrå, Wolff oraz Biuro Prasowe Jugosłowiańskie. W następnych latach dołączyły jeszcze rosyjska TAss oraz amerykańska $\mathrm{AP}^{17}$.

Zadaniem Międzynarodowego Związku Agencji Informacyjnych było wypracowanie standardów i praktyk dotyczących wspólnej pracy. Poruszano palące kwestie dla wszystkich agencji, takie jak: ochrona własności informacji prasowych, zasady handlowe czy wprowadzanie nowinek technologicznych. W trakcie kolejnych konferencji Międzynarodowego Związku Agencji Informacyjnych rozmawiano o roli połączeń telefonicznych, sprawności systemu telegraficznego czy unifikacji kodów stosowanych w transmisjach telegraficznych. Konferencje służyły też definiowaniu zagrożeń dla nowego podziału świata informacji i próbie rozwiązania tych problemów. Już na pierwszym spotkaniu w Bernie stworzono listę „agencji niezrzeszonych”. Takimi problematycznymi podmiotami, z punktu widzenia Międzynarodowego Związku Agencji Informacyjnych, były między innymi Transradio i Europaradio. Ostatecznie agencjom sprzymierzonym udało się wyprzeć tych dwóch graczy z rynku.

Co ciekawe, trzecia konferencja MzA odbyła się w Warszawie. Działo się to pod koniec maja 1927 roku. Zapadła na niej decyzja o utworzeniu serwisów sportowych we wszystkich agencjach prasowych oraz o ścisłej współpracy w tej dziedzinie. Nie obyło się bez atrakcji. Były dyrektor Polskiej Agencji Telegraficznej Roman Starzyński pisał: „konferencja warszawska, dzięki zorganizowanym wycieczkom do Krakowa, Szczawnicy i Zakopanego, przyczyniła się bardzo do zacieśnienia stosunków osobistych między

17 Tamże, s. 19. 
kierownikami agencyj sprzymierzonych"18. Podobno wszyscy bawili się wybornie, choć kroniki miejskie na ten temat solidarnie milczą ${ }^{19}$.

\section{Co II wojna światowa zrobiła $\mathrm{z}$ agencjami}

II wojna światowa przyczyniła się też do zmian na rynku agencji prasowych. Ofiarami konfliktu stały się nie tylko tysiące niewinnych ludzi, lecz także agencja Havas i agencja Wolffa. Żeby zrozumieć, co się wydarzyło, należy się cofnąć do pierwszej połowy lat 3o. Xx wieku. W roku 1933 do władzy w Niemczech doszło NSDAP, partia nazistowska, która miała plan na odbudowę kraju. Rok po przejęciu władzy pojawił się pomysł nacjonalizacji mediów. Celem tego działania były poprawa jakości komunikatów propagandowych oraz lepsza kontrola informacji. Ofiarą pomysłu staje się agencja Wolffa. Uznano bowiem, że lepszym rozwiązaniem jest znacjonalizowanie już istniejącej agencji niż tworzenie takiego podmiotu od zera, zwłaszcza że agencja Wolffa miała już swoją renomę, duży zasięg oraz, co najważniejsze, sieć korespondentów i zaplecze technologiczne. Tak właśnie w 1934 roku agencja Wolffa odeszła do historii, ponieważ przemianowano ją na Deutsche Nachrichtenbüro (DNB). Agencja ta utrzymała się do końca II wojny światowej i przestała istnieć wraz z kapitulacją III Rzeszy. $\mathrm{W}$ jej miejsce powstały dwie agencje informacyjne, po jednej na każdą z połówek podzielonego Berlina. Ocena działania DNB przez wzgląd na historię jest jednoznaczna. Doszukując się plusów, można powiedzieć, że agencja dość sprawnie relacjonowała działania wojsk na frontach ${ }^{20}$.

Upadek Havas, w odróżnieniu od poprzedniej opisywanej agencji, nastąpił już w trakcie II wojny światowej. Wraz z kapitulacją Francji w 1940 roku i powstaniem tak zwanego Państwa Francuskiego pod dowództwem marsz. Pétaina agencja straciła swoją niezależność i trafiła w ręce Ministerstwa Informacji ${ }^{21}$. Podobnie jak w przypadku agencji Wolffa, zmienionej w DNB, rządowi francuskiemu nie opłacało się tworzyć nowych struktur. Agencję Havas upaństwowiono wraz z jej majątkiem. Ministerstwo Informacji prze-

18 Tamże, s. 25.

19 Tamże, s. 18-28.

20 A. Char, La guerre mondiale de l'information, Quebec 1999, s. 57.

21 H. Kurta, L. Meissner, Prasa za granica, dz. cyt., s. 88. 
mianowało ją na Biuro Informacyjne (Office Francais d'Information). Organizacja opierała się głównie na dwóch ośrodkach po linii władzy, czyli Vichy i Clermont-Ferrand ${ }^{22}$. Paryskie lokale należące do Havas przekształcono we francuską filię Deutsche Nachrichtenbüro, którą nazwano Francuską Agencją Informacji Prasowych (AFIP). Wraz z zamknięciem biura w stolicy Francji z pracą pożegnali się korespondenci zagraniczni, a wszystkie filie i oddziały zagraniczne zostały zamknięte. Dziennikarze pracujący dotychczas w centrali Havas zostali przejęci wraz ze sprzętem i do końca wojny pisali dla okupantów. Zaczął się najczarniejszy okres w dziejach agencji. Havas pod nazwą Francuskiego Biura Informacyjnego stał się propagandową tubą rządu w Vichy. Celem agencji nie było gromadzenie rzetelnych informacji, tylko gloryfikowanie okupanta ${ }^{23}$. Co ciekawe, kontrolowane przez nazistów i kolaborantów BI oraz AFIP nie były jedynymi francuskimi agencjami prasowymi działającymi w trakcie II wojny światowej. Jako przeciwwaga do informacji reżimowych powstały: Niezależna Agencja Francuska z siedzibą w Londynie, na terenie okupowanej Francji istniały Agencja Informacji i Dokumentacji (AID) oraz agencja France Libre, która obsługiwała prasę ruchu oporu związanego z gen. de Gaulle'em. Po wojnie wszystkie te agencje zostały połączone w Agence France-Presse (AFP) ${ }^{24}$. Agencja AFP przejęła lokale i sprzęt po przedwojennej agencji Havas. Obecny status AFP przyjęty został w styczniu 1957 roku. Był to wynik swoistego kompromisu między dążeniem prasy do zachowania niezależności od państwa, uznaniem potrzeby istnienia agencji państwowej a między innymi uzasadnioną niemożnością uzyskania z innych źródeł ogromnych funduszy, niezbędnych dla pokrycia wydatków współczesnej agencji prasowej. Status z 1957 roku dał świetnej francuskiej agencji jej dalszą niezależność od rządu, gwarantowaną przez Wysoką Radę złożoną z osobistości spoza aktualnej władzy ${ }^{25}$.

Sytuacje AFP po wojnie opisał B. Golka. O dopiero co odbudowanej redakcji pisał: „Cała ta skomplikowana struktura służy głównie zachowaniu pozorów niezależności. W rzeczywistości jednak Agencja France-Presse uchodzi za instytucję państwową, wyrażającą poglądy rządu. Zapewnia ona dopływ informacji z całego świata do prasy francuskiej oraz

22 M. B. Palmer, Des petit journaux aux grandes agences: naissance du journalisme moderne, 1863-1914, Paryż 1983, s. 203.

23 Tamże, s. 203.

24 H. Kurta, L. Meissner, Prasa za granica, dz. cyt., s. 89.

25 H. Piaget, Les Agences de presse: institution du passe ou media d'avenir, Paryż 1997, s. 66. 
licznych abonentów zagranicznych. Oprócz Agencji France-Presse istnieje we Francji kilka znacznie mniejszych agencji zaopatrujących prasę lub innych odbiorców w określone materiały (zdjęcia, informacje specjalne) [...] Rządy są «zmienne», odradzająca się francuska prasa jest słaba, a państwo, które ma na celu przywrócenie jej międzynarodowego prestiżu, powinno wspierać finansowo agencję, która ma odbudować zarówno sieć korespondentów i jej globalną publiczność”26. Pierwsza filia zagraniczna została uruchomiona w Chinach, gdzie AFP utrzymuje się nawet dzisiaj i ma uprzywilejowaną pozycję.

Praca AFP w błyskawicznym tempie zaczęła przynosić rezultaty. Szybkość, z jaką agencja poinformowała świat o śmierci Stalina 6 marca 1953 roku, jest najlepszym przykładem jej rozwoju. Poprzez swoje usługi monitoringu radia w Moskwie i innych stolicach Europy Wschodniej AFP zdążyła wypuścić depesze o śmierci wodza piętnaście minut przed oficjalnym ogłoszeniem jej przez Radio Moskwa ${ }^{27}$. Podobno jako pierwsza w Polsce o śmierci Stalina poinformowała pogodynka „Chmurka”. W trakcie prognozy pogody miała powiedzieć: „Na Wschodzie minus jeden”, co miało sugerować, że wielki wódz Sowietów zmarł. Ile w tym prawdy, nie wiadomo. Dziś AFp komunikuje się głównie przez internet. Jest to wyznacznik naszych czasów. Agencja kontynuuje tradycje agencji Havasa, ma 9 biur krajowych i ponad 100 zagranicznych, także w Polsce. Przekazuje serwisy informacyjne (w 6 językach, codziennie ponad 2 miliony słów), odbiera około 165 krajów - w tym 42 afrykańskie i 18 bliskowschodnich; przygotowuje serwisy dla 12 tysięcy gazet, kilkuset rozgłośni radiowych i stacji telewizyjnych oraz 99 agencji prasowych. AFP uznawana jest za agencję światową (jako jedyna nieanglosaska) ${ }^{28}$.

W okresie II wojny światowej również powstawały agencje prasowe. Na przykład 5 listopada 1943 roku została powołana do życia Telegrafska Agencija Nova Jugoslavija (Tanjug). Założono ją w małym miasteczku Jajka na terenie Bośni i Hercegowiny. Z racji tego, że w Jugosławii toczyły się jeszcze walki, siedziba Tanjugu przenosiła się wraz ze zmianą frontu i tak z Jajki trafiła na wyspę Vis, żeby ostatecznie, po wyzwoleniu kraju, zadomowić się w Belgradzie. Co było motorem napędowym powstania

26 B. Golka, Prasa radio i telewizja na świecie, Warszawa 1980, s. 107.

27 http://expositions.bnf.fr/afp/arret/1/index.htm, 22.05.2021.

28 Media: leksykon PWN, dz. cyt., s. 9. 
agencji i dlaczego akurat w Jajce? Okazuje się, że był to zbieg okoliczności. Akurat tam jugosłowiańscy antyfaszyści przygotowywali się do II sesji Antyfaszystowskiej Rady Wyzwolenia Narodu Jugosławii. „Istniała wówczas polityczna i społeczna potrzeba powołania do życia instytucji informacyjnej, która informowałaby opinię publiczną Jugosławii i świata o celach i programie antyfaszystowskiego ruchu wyzwoleńczego" ${ }^{29}$. Brzmi dość absurdalnie, ale takie były czasy. Grunt, że w czasie, gdy wszystko się rozpadało, udało się jednak stworzyć agencję prasową, i to całkiem dynamiczną. Po wojnie Tanjug nawiązał współpracę z AFP, Reutersem, TAss i 34 innymi agencjami prasowymi. Agencja działa do dziś na terenie Serbii.

\section{Dwie agencje niemieckie i ich sposób postrzegania świata}

Po II wojnie światowej rynki zaczęły się powoli stabilizować. Zadanie to jednak było utrudnione w Niemczech. Nie chodzi tylko o fakt przegranego konfliktu globalnego, ale o podział na cztery, a później dwie strefy wpływów, z których powstały na zachodzie Republika Federalna Niemiec i na wschodzie Niemiecka Republika Demokratyczna. Sąsiedzi na każdym kroku chcieli pokazać swoją odrębność, więc nie może dziwić fakt powołania dwóch osobnych agencji informacyjnych. „Agencję «Allgemeiner Deutscher Nachrichtendienst» (ADN) powołano do życia 10 października $1946{ }^{30} \mathrm{~W}$ ówczesnej radzieckiej strefie okupacyjnej Niemiec. W tłumaczeniu Adn oznacza Powszechną Niemiecką Służbę Prasową. Za jej powołaniem stali wydawcy dzienników, które ukazywały się w tej strefie okupacyjnej. Nietrudno zgadnąć, że reprezentowała ona interesy partii antyfaszystowskich. 2 kwietnia 1953 roku ADN została uznana za oficjalną agencję NRD. Na jej siedzibę wybrano demokratyczną część Berlina. W 1956 roku dołączono do niej agencję fotograficzną Zentralbild. ADN w momencie istnienia i swego rozkwitu miała oddziały terenowe we wszystkich większych miastach NRD oraz ważniejszych ośrodkach na świecie, takich jak Nowy Jork, Londyn, Paryż czy - z racji profilu i ówczesnego „braterstwa myśli socjalistycznej” - w Warszawie i Moskwie.

29 H. Kurta, L. Meissner, Prasa za granica, dz. cyt., s. 16o.

30 Tamże, s. 182. 
Ciekawostką może być fakt, że posiadała również korespondenta na Zanzibarze. Głównymi współpracownikami ADN były wielkie agencje prasowe, $\mathrm{z}$ agencją TASs na czele, ale $\mathrm{w}$ tym gronie - może $\mathrm{z}$ racji sąsiedztwa, może z powodu dobrych relacji - znalazła się także Polska Agencja Prasowa ${ }^{31}$.

Trzy lata po powstaniu ADN w zachodniej części Niemiec, dokładnie „1 września 1949 r. obwieściła swe powstanie wielka agencja niemiecka Deutsche Presse-Agentur, w skrócie DPA" ${ }^{32}$, czyli Niemiecka Agencja Prasowa. Dla odmiany nowo powstała siła medialna na swoją siedzibę, zamiast konkurencyjnej części Berlina, wybrała Hamburg. DPA zrodziła się wskutek fuzji trzech dużych agencji pochodzących $\mathrm{z}$ alianckich stref okupacyjnych, amerykańskiej Deutsche Nachrichtenagentur (DENA), francuskiej Südwestdeutsche Nachrichtenagentur (Südena) oraz brytyjskiej Deutscher Pressedienst GmbH (DPD). Podobnie jak konkurencyjna ADN agencja w swoim portfolio mogła pochwalić się obsługą wszystkich największych ośrodków życia politycznego na świecie. Dziennikarze DPA dostarczali bardzo urozmaiconego kontentu. Począwszy od depesz, komentarzy od korespondentów, a na serwisie fotograficznym kończąc. Skoro głównym partnerem agencyjnym dla ADN była rosyjska TASs, nietrudno się domyślić, że DPA najsilniej współpracowała z Reutersem. W okresie zimnej wojny Deutsche Presse-Agentur uchodziła za największą niemiecką agencję prasową. Porównywano ją do agencji Wolffa, co mogło być powodem do dumy. Złośliwi jednak lubili mówić o niej, że jest dobrym spadkobiercą DNB Z okresu III Rzeszy ${ }^{33}$.

Jak zatem wyglądała praca agencji w tamtym czasie? Trochę światła na ten temat rzucił Lucjan Meissner. W 1972 roku w książce Prasa za granicq opisywał: „Informacja polityczna ADN, poświęcona faktom i wydarzeniom w Niemieckiej Republice Federalnej, odróżnia się bardzo wyraźnie od serwisu zachodnioniemieckiej agencji DPA. Różnica ta polega przede wszystkim na odmiennym, a niekiedy wręcz przeciwstawnym kierunku selekcji faktów. O ile działalność sił postępowych w NRF - Związku Ofiar Faszyzmu, Niemieckiej Partii Komunistycznej, Niemieckiej Unii Pokoju, postępowych intelektualistów, studentów, lewicowych socjalistów i związkowców, nie znajduje w serwisach DPA należytego odzwier-

31 Tamże, s. 204.

32 Tamże, s. 202.

33 Tamże, s. 204. 
ciedlenia, o tyle w serwisie ADN poświęca się temu nurtowi bardzo dużo miejsca. Każdy ważniejszy fakt, będący przejawem aktywności tego nurtu, jest przez oficjalną agencję NRD skrupulatnie odnotowywany"34. Ten dysonans wynikał z faktu, że obydwie agencje, tak jak każde medium, były łączone z konkretną grupą interesów. Pamiętajmy, że działo się to w okresie zimnej wojny. ADN z racji przynależności do strefy radzieckiej musiała się wykazać zaangażowaniem w sprawy ważne dla Sowietów. DPA była po drugiej stronie, więc reprezentowała myślenie proamerykańskie. Tekst Lucjana Meissnera został opublikowany w latach 70. - wtedy nawet pisząc o Zachodzie, trzeba było dobrze mówić o Wschodzie.

\section{Polacy nie gęsi i swe agencje mają}

Z. Bajka w książce Historia mediów przytacza mało znany fakt, że drugą agencją prasową w Europie wcale nie było przedsięwzięcie Wolffa, lecz austriacka agencja Josepha Tuwary. Powstała ona we wrześniu 1849 roku, a warto o niej pamiętać dlatego, że „działała na części ziem polskich, a jej umocnienia i «upaństwowienia» dokonał Polak - Agenor Romuald Onufry hr. Gołuchowski - minister spraw wewnętrznych Austro-Węgier, potem premier, wcześniej namiestnik Galicji” ${ }^{35}$. Pierwszą prawdziwie polską agencją była Polska Agencja Telegraficzna. Powstała w 1918 roku, kiedy grupa polskich dziennikarzy przejęła oddziały Wiedeńskiego Biura Korespondencyjnego w Krakowie i we Lwowie ${ }^{36}$. Ciekawostką związaną z Polską Agencją Telegraficzną jest fakt, że ich serwis agencyjny był ogłaszany przez megafon $\mathrm{w}$ pociągach ${ }^{37}$. PAT jednak nie była jedyną agencją o polskim rodowodzie. W 1925 roku w Warszawie powołano Polską Agencję Publicystyczną. Była to agencja ogólnoinformacyjna, założona przez konserwatystów, takich jak Jan Goetz-Okocimski oraz Wojciech Rostworowski ${ }^{38}$. W okresie dwudziestolecia międzywojennego „istniało ponad 50 agencji prasowych, z których większość miała efemeryczny charakter, bądź prowadziła działalność mającą niewiele wspólnego z rozpowszech-

34 Tamże, s. 184.

35 Z. Bajka, Historia mediów, dz. cyt., s. 72.

36 R. Borkowski, Informacyjne agencje prasowe, dz. cyt., s. 94.

37 R. Starzyński, Agencje informacyjne, dz. cyt., s. 29.

38 R. Piasecka-Strzelec, Polskie agencje prasowe w rozwoju historycznym, Kraków 2019, s. 54. 
nianiem rzetelnych informacji dla prasy. Do tej grupy zaliczyć należy m.in. Prasowe Biuro Kresowe, agencję o nazwie Korespondencja Polonia, agencję Varsovia, Telegraficzną Agencję Górnośląską Rekord (nazwaną agencją bluffów) oraz agencję Polpress" 39 .

W latach 30. powstawały agencje lokalne. Warszawa przestała być jedynym ośrodkiem informacyjnym. Takie agencje „istniały w Bydgoszczy, Grudziądzu, Gdyni, Poznaniu, Wilnie i Lwowie. Wydawały one biuletyny o zróżnicowanej problematyce poświęconej zarówno zagadnieniom regionalnym, jak i zjawiskom w skali ogólnopolskiej, głównie kwestiom natury ekonomiczno-politycznej. Ważniejszymi prowincjonalnymi agencjami lokalnymi były: Portowa Agencja Prasowa, Portowa Agencja Prasowo-Handlowa, Agencja Północna (wszystkie trzy z siedzibą w Gdyni), Pomorska Agencja Prasowa w Grudziądzu, Morska Agencja Telegraficzna w Bydgoszczy, Agencja Śląska w Katowicach, Bałtycka Agencja Prasowa w Wilnie, Południowo-Wschodnia Agencja Prasowa we Lwowie i agencja informacyjno-publicystyczna Zachód w Poznaniu" ${ }^{40}$. Istniały również agencje specjalistyczne, takie jak Agencja Wschodnia, która zajmowała się tematyką gospodarczo-handlową, czy Polska Agencja Agrarna odpowiedzialna za informacje z życia wsi.

Historia Polskiej Agencji Telegraficznej silnie związana jest z Polską Agencją Prasową. Założona 26 października 1945 roku PAP niejako jest spadkobiercą i powojennym kontynuatorem dzieła Polskiej Agencji Telegraficznej. Pomimo wszystkich uprzejmości i sympatii do siebie dopiero w roku 1991 symboliczne połączono obydwie agencje. Ostatni redaktor PAT Ferdynand Pasiecznik przekazał ówczesnemu prezesowi PAP Ignacemu Rutkiewiczowi kopie serwisów informacyjnych Polskiej Agencji Telegraficznej. Od tej chwili PAP działa jako oficjalny spadkobierca PAT. W 1991 roku przyłączono również do agencji Centralną Agencję Fotograficzną ${ }^{41}$.

Początek lat 9o. był momentem narodzin Katolickiej Agencji Informacyjnej. Założono ją w 1993 roku z inicjatywy Konferencji Episkopatu Polski. Zadaniem KaI jest promocja Kościoła katolickiego wobec mediów świeckich. Do zadań KaI należy przekazywanie wiadomości o życiu religijnym oraz zjawiskach religijno-społecznych na całym świecie, ze

39 Tamże, s. 54 .

40 Tamże, s. 86.

41 http://www.pap.pl/o-agencji/\#sthash.mQLmSPPA.dpuf, 22.05.2021. 
szczególnym uwzględnieniem regionu Europy Środkowej i Wschodniej. Agencja służy swoimi informacjami mediom i instytucjom kościelnym (3,5 tysiąca parafii i innych ośrodków kościelnych prenumeruje „Biuletyn KAI”). Agencja jest drugą co do wielkości katolicką agencją w Europie ${ }^{42}$. KAI aktywnie obsługuje największe uroczystości kościelne w Polsce. Reporterów agencji można było spotkać w trakcie wszystkich pielgrzymek papieskich do naszego kraju, a także Światowych Dni Młodzieży w Krakowie. KAI nie jest jednak pierwszą katolicką agencją działającą w Polsce. W 1927 roku ks. Józef Gawlina założył Katolicką Agencję Prasową. Dostarczała ona informacji o wydarzeniach religijnych w kraju i na świecie, a także opisywała życie polityczne. Biuletyny KAP trafiały nie tylko do prasy polskiej, lecz także do zagranicznych tytułów takich jak „L’Osservatore Romano” czy „La Croix” ${ }^{43}$.

Nowe tysiąclecie rozpoczęło się od przyjęcia Polskiej Agencji Prasowej do grona członków Europejskiej Agencji Fotograficznej EPA (European Pressphoto Agency). Stało się to w 2001 roku. Od połowy lat 9o. agencja stopniowo była digitalizowana. Depesze PAP są dziś udostępniane przez portal oraz platformy cyfrowe. Agencja oprócz swojej strony internetowej posiada dwie platformy do dystrybuowania zdjęć, bazę zdjęć fotobaza. pap, czyli cyfrowe archiwum, oraz fotoserwis.pap udostępniający zdjęcia z aktualnych wydarzeń. „Polska Agencja Prasowa wydaje serwisy krajowe i zagraniczne, biuletyny i informatory, informacyjne i publicystyczne serwisy prasowe (w języku polskim, angielskim); ma 24 biura krajowe, 18 stałych korespondentów zagranicznych i 36 krajowych; otrzymuje informacje od 44 agencji $z$ całego świata i codziennie przekazuje serwis depeszowy (ponad 6oo depesz) do prasy krajowej, radia i TV"44. Zbiera, opracowuje i przekazuje obiektywne i wszechstronne informacje z kraju i zagranicy. Przez całą dobę, siedem dni w tygodniu 250 dziennikarzy i 40 fotoreporterów przygotowuje serwisy informacyjne, z których korzystają media, instytucje, urzędy państwowe i przedsiębiorcy ${ }^{45}$.

42 Media: leksykon PWN, dz. cyt., s. 184.

43 R. Piasecka-Strzelec, Polskie agencje, dz. cyt., s. 82.

44 Media: leksykon PWN, dz. cyt., s. 155.

45 http://www.pap.pl/o-agencji/\#sthash.mQLmSPPA.dpuf, 22.05.2021. 


\section{Zakończenie}

Przez ostatnie prawie dwieście lat agencje prasowe przeszły dużą przemianę. Ich sposób dostarczania informacji ewoluował z depesz przyczepionych do gołębi pocztowych w multimedialne platformy dostępne z każdego miejsca na ziemi. Technologia, której rozwój zawsze przyspieszał pracę agencji, stała się jednak zagrożeniem. Media społecznościowe sprawiły, że dziś każdy może być jednoosobową agencją prasową. W natłoku informacji trudno oddzielić newsy od fake newsów. Przeskoczyliśmy z poziomu człowieka, który musiał zaufać gołębiowi, że trafi z jego wiadomością do właściwego adresata i nie padnie po drodze ofiarą żadnego drapieżnika, do poziomu, na którym musimy się zastanowić, czy podawany dalej tweet jest prawdziwy. Już nie wyszukiwanie informacji, ale fact-checking jest dziś najważniejszym zadaniem agencji prasowych. Globalne agencje tworzą nawet swoje serwisy, gdzie dementują albo potwierdzają wiadomości, które budzą ich wątpliwości. Paradoksalnie historia zatoczyła koło. Przecież jednym z powodów, dla których powstały agencje prasowe, była walka $\mathrm{z}$ nieprawdziwymi informacjami dostarczanymi przez nierzetelnych korespondentów. Historia agencji prasowych pokazuje, jak zmieniał się świat i jak zmieniała go polityka. Przykładem może być przypadek agencji Havas. Zapisała się ona na kartach historii jako pierwsza agencja prasowa, a później została skompromitowana przez decyzje polityczne. Polityka jest motorem napędowym dla wszystkich agencji, ich głównym źródłem newsów. Dziennikarze agencji informacyjnych uczestniczyli we wszystkich konfliktach zbrojnych, wyborach, informowali o zamachach, relacjonowali koronacje czy ważniejsze wydarzenia kulturowe w ciągu ostatnich około dwustu lat. Są zawsze tam, gdzie dzieje się historia, i to na pewno się nie zmieni. 